\title{
Effect of Soaking and Boiling on Anti-nutritional Factors, Oligosaccharide Contents and Protein Digestibility of Newly Developed Bambara Groundnut Cultivars
}

\author{
Olaposi Rafiu Adeleke $^{1 *}$, Oladipupo Qudus Adiamo ${ }^{2}$, Olumide Samson Fawale ${ }^{1}$, \\ Gbeminiyi Olamiti ${ }^{3}$
}

${ }^{I}$ Department of Food Science and Technology, Faculty of Technology, Obafemi Awolowo University, Ile-Ife, Osun State, Nigeria

${ }^{2}$ Department of Food Science and Nutrition, College of Food and Agricultural Sciences, King Saud University, P.O. Box 2460, Riyadh 11451, Kingdom of Saudi Arabia

${ }^{3}$ Department of Food Science and Technology, School of Agriculture, University of Venda, Thohoyandou 0950, South Africa

\section{A R T I C L E I N F O}

\section{Research Article}

Received 12 August 2016

Accepted 09 July 2017

Keywords:

Bambara groundnut

Soaking

Boiling

Anti-nutrients

Oligosaccharides

Protein digestibility

*Corresponding Author:

E-mail: adeleke.olaposi@yahoo.com

\section{A B S T R A C T}

Newly developed Bambara groundnut (Vigna subterranea L.) seeds (Accessions No: TVSU 5 - Bambara Groundnut White (BGW) and TVSU 146 - Bambara Groundnut Brown (BGB)) were collected from International Institute of Tropical Agriculture (IITA), Nigeria, planted and harvested. The effects of processing methods (soaking and boiling) on anti-nutritional factors and oligosaccharides content and protein digestibility of BGW and BGB compared with Bambara groundnut commercial (BGC) seeds were investigated. Soaking and boiling significantly reduced the anti-nutritional factors of the samples and the effect increased as processing time was elongated. Sample BGC had lower anti-nutritional factors than BGW and BGB after soaking for $48 \mathrm{~h}$. Tannin contents of the samples were reduced drastically by $99 \%$ throughout the soaking periods. Greatest loss in raffinose level was observed in BGB (59\%) and BGW (50\%) after boiling for 60 min compared with BGC (43\%). The loss in stachyose content of the samples varies with processing and $\mathrm{BGC}(59 \%)$ had greatest loss after boiling for $60 \mathrm{~min}$ while soaking for 48 $\mathrm{h}$ reduced that of BGB and BGW by 57 and 35\%, respectively. Boiling for $60 \mathrm{~min}$ increased the in vitro protein digestibility of BGB (89.34\%) compared with BGW $(87.48 \%)$ and BGC $(82.89 \%)$. Overall, the results demonstrated that soaking and boiling of newly developed Bambara groundnut seeds could improve the nutritive quality of the seeds.

DOI: https://doi.org/10.24925/turjaf.v5i9.1006-1014.949

\section{Introduction}

A significant part of the human world population relies on legumes as their main source of proteins. Nonetheless, production of common legumes may not keep pace with population growth due to adverse weather conditions and consequently decline per head capital availability. In rural South Western Nigeria, legumes are often advocated to be included in diets by Nigerian Nutrition Society and National Committee on Food and Nutrition (NCFN) due to their high nutritional values and low cost (Akinjayeju and Bisiriyu, 2004). Intensive efforts to find alternative sources of proteins from plants adapted to adverse conditions have been conducted (Adebowale and Lawal, 2003; Akinjayeju and Bisiriyu, 2004) with little success. However, most of the indigenous legumes in Nigeria and in the tropics are relatively underutilized (Bryan, 2000).

Bambara groundnut (Vigna subterranea L.) is one of the indigenous underutilized legumes that are now grown across Africa (Adebowale and Lawal, 2003). It is an herbaceous, intermediate, annual plant, with creeping stems at ground level. Bambara groundnut can grow under conditions unsuitable for groundnut and had tolerance for drought and poor soil (Agbenorhevi et al., 2007). The seed contains about 19.60-21.42\% crude protein and about $3.33-6.50 \%$ crude fat (Fadahunsi and Sanni, 2010; Fadahunsi et al., 2011; Okonkwo and Opara, 2010). It is usually fried or boiled with salt and eaten as snacks or pounded into flour and used in the preparation of soup, porridge and various fried or steamed food products such as akara, moin-moin and okpa in Nigeria. Adebowale et al. (2005) reported that bambara groundnut flour has been used in making bread in Zambia. Piyarat (2008) noted that the milk prepared from bambara groundnut gave a preferred flavour to that of milks from cowpea, pigeon pea and soybean.

Some of the factors that limit the utilization potential of indigenous legumes include presence of anti-nutrients (trypsin, chymotrypsin, $\alpha$-amylase inhibitors, phytic acid, 
flatus factors, saponin and lectins), low contents of sulphur amino acids and the long cooking period required to eliminate those anti-nutritional factors (Genta et al., 2002). Furthermore, the presence of indigestible substances such as the flatulence-producing oligosaccharides, namely raffinose, stachyose and verbascose has also contributed to their reduced utilization as human foods (Aremu et al., 2006).

The nutritive value of legumes depends upon the processing methods, presence or absence of antinutritional or toxic factors and possible interaction of nutrient with other food component (Ghadge et al., 2008). The level of anti-nutritional factors in legumes need to be reduced in order to improve the nutritional quality and enhance effective utilization of the legume for human consumption. So it is necessary to establish processing techniques to ensure its optimal utilization. In order to inactivate or reduce anti-nutrients, various conventional, simple processing methods have been used in legume seeds (Barbour et al., 2001; Farran et al., 2001).

Heat processing is widely accepted as an effective means of inactivating the thermo-labile antinutritional factors of legume grains. Cooking, autoclaving, pressure cooking, extrusion cooking and microwave treatment are some of the heat processing treatments commonly applied to legume grains before their consumption (Osungbade et al., 2016; El-Adawy, 2002; Khokhar and Chauhan, 1997; Alonso et al., 2000). They reported that these improved protein quality by inactivating anti-physiological factors particularly trypsin inhibitors and haemagglutinins by unfolding the protein structure, thus making them more susceptible to attack by digestive enzymes. Moist heat has been reported to be more effective than dry heat and the degree of inactivation is governed by temperature, duration of heating and particle size. Other treatments reported to have reduced the undesirable constituents of legume grains include soaking (Khokhar and Chauhan, 1997), germination (Wang et al., 2009), irradiation (Ghadge et al., 2008) as well as chemical treatments (Fernandez et al., 1993).

In spite of the growing importance of bambara groundnut, research efforts in Nigeria have been concentrated on its agronomy. Little or no attention has been paid to the technologies for its processing. Furthermore, much of the available data and information on the anti-nutrient composition are limited to the commonly used variety. This is because of the possible effects of variety/genetic origin, climate, soil, pesticides and fertilizers on the chemical composition of the new varieties. Therefore, the aim of this study was to determine the effects of soaking and boiling on anti nutritional factors and oligosaccharides contents and protein digestibility of newly developed Bambara groundnut cultivars.

\section{Materials and Methods}

\section{Collection of Raw Materials}

Figure 1 shows the new varieties of Bambara groundnut seeds and the commercial sample used in this study. Two new varieties of bambara groundnut (Vigna subterranea L.) seeds (Accessions No: TVSU 5 Bambara Groundnut White (BGW) and TVSU 146 Bambara Groundnut Brown (BGB) were collected from the International Institute of Tropical Agriculture (IITA), Ibadan, Oyo State, Nigeria. The seeds were multiplied by planting on a special and demarcated farm at Kelebe, Osogbo, Osun State, Nigeria. The ripe, matured and dried pods were harvested after 160 days. The pods were sun dried and threshed to obtain the seeds. Bambara groundnut commercial (BGC) seeds were purchased from a local market in Oyo, Nigeria. All the seeds were washed with clean tap water to remove dirt and other adhering materials, sun dried and stored in air tight containers for analysis. All chemicals used were of analytical grade.

\section{Preparation of Raw, Soaked and Boiled Bambara Groundnut Seeds Flour}

Raw flour was prepared by steeping $500 \mathrm{~g}$ of bambara groundnut seeds in distilled water for $30 \mathrm{~min}$, decorticated by rubbing between palms and the seed coats were washed away with tap water. Soaking was done according to the method described by Udensi et al. (2008) with slight modification. The seeds were soaked in distilled water $(1: 10 \mathrm{w} / \mathrm{v})$ at room temperature $\left(30 \pm 2^{\circ} \mathrm{C}\right)$ for 12,24 and $48 \mathrm{~h}$ thereafter the soaked seeds were washed twice with ordinary water, followed by rinsing with distilled water, drained and dehulled. Boiling was carried out by heating the seeds in distilled water at $100^{\circ} \mathrm{C}$ (sample: water ratio; 1:10) for 30 and $60 \mathrm{~min}$, drained and dehulled. All the treated samples were dried at $40^{\circ} \mathrm{C}$ in a hot air oven (UNISCOPE SM 9053, England) to about $10 \%$ moisture content. The dried samples were milled using Marlex Excella grinder (Marlex Appliances PVT, Daman) and sieved through $0.2 \mathrm{~mm}$ sieve to obtain homogenous flour that were kept in air tight containers and refrigerated at $4^{\circ} \mathrm{C}$ for further analyses.
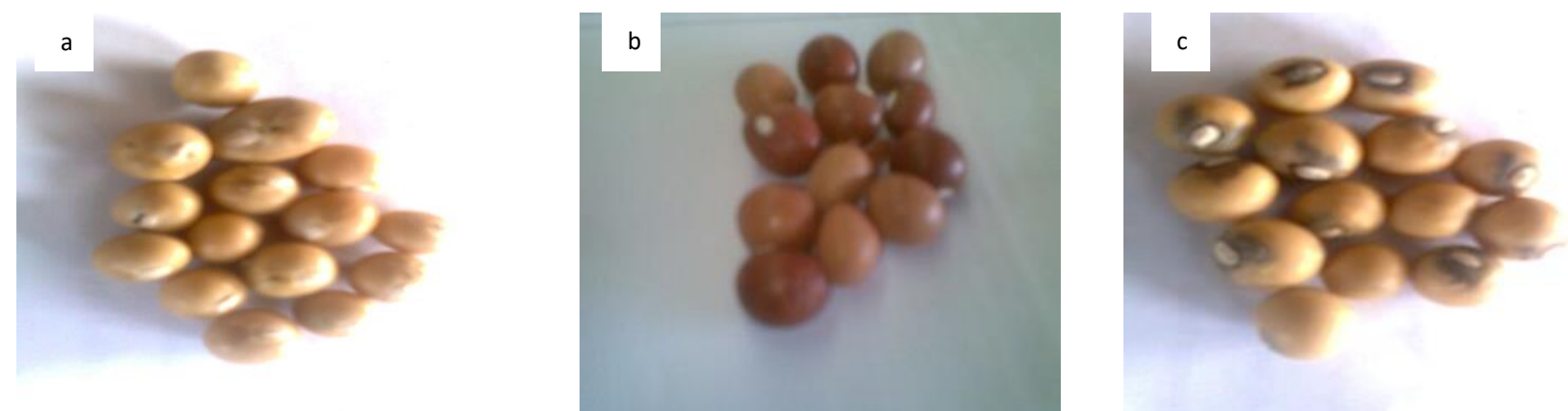

Figure1 Varieties of Bambara groundnut seeds a) Accession No: TVSU-5 variety (Bambara Groundnut White -BGW), b) Accession No: TVSU-146 variety (Bambara Groundnut Brown- BGB), c) Bambara Groundnut Commercial- BGC 


\section{Oxalate Level Determination}

Oxalate was determined by the method described by Falade et al. (2005) with slight modification. Two grams of the sample was extracted with $190 \mathrm{~mL}$ of distilled water and $10 \mathrm{~mL}$ of $6 \mathrm{M} \mathrm{HCl}$ in boiling water for $2 \mathrm{~h}$, filtered and made up to $250 \mathrm{~mL}$ with water. An aliquot $(50 \mathrm{~mL})$ of the filtrate was titrated against $\mathrm{NH}_{4} \mathrm{OH}$ until the salmon pink of the methyl red indicator changed to a faint yellow. The solution was heated to $90^{\circ} \mathrm{C}$ and $10 \mathrm{~mL}$ of $5 \%(\mathrm{w} / \mathrm{v}) \mathrm{CaCl}_{2}$ solution was added to precipitate the oxalate overnight. The precipitate was washed free of calcium and then washed into a $100 \mathrm{~mL}$ conical flask with $10 \mathrm{~mL}$ of hot $\mathrm{H}_{2} \mathrm{SO}_{4}(25 \% \mathrm{v} / \mathrm{v})$ and then with $15 \mathrm{~mL}$ distilled water. The final solution was heated to $90^{\circ} \mathrm{C}$ and titrated against a standardized $0.1 \mathrm{M} \mathrm{KMNO}_{4}$ until a faint purple color of the solution persisted for $30 \mathrm{~s}$. The oxalate was then calculated as the sodium oxalate equivalent from the mole ratio.

\section{Tannin Content Determination}

Vanillin- $\mathrm{HCl}$ method was used to assay tannin content according to the modified method of Price and Butler (1977). Briefly, extraction was done by adding $1 \mathrm{~g}$ of sample to $50 \mathrm{~mL}$ methanol. The mixture was stirred for 20-28 $\mathrm{h}$ and centrifuged to obtain the supernatant. Exactly $1 \mathrm{~mL}$ of supernatant was added to $5 \mathrm{~mL}$ of vanillin hydrochloric acid reagent (equal volumes of $8 \%$ hydrochloric acid in methanol and 4\% vanillin in methanol). A standard catechin solution (20-100 $\mu \mathrm{g}$ ) was prepared and used as reference standard. The absorbance of sample and standard solutions were read after $20 \mathrm{~min}$ in Jenway V6300 spectrophotometer at $500 \mathrm{~nm}$.

\section{Phytate Content Determination}

Phytate content was determined by the method described by Wheeler and Ferrel (1971) using $2.0 \mathrm{~g}$ dried sample. A standard curve was prepared expressing the results as $\mathrm{Fe}\left(\mathrm{NO}_{3}\right)_{3}$ equivalent. Phytate phosphorus was calculated from the standard curve assuming a 4:6 iron to phosphorus molar ratio.

\section{Saponin Content Determination}

The spectrophotometric method of Brunner (1984) was used for saponin analysis using $1 \mathrm{~g}$ of sample. Standard saponin solutions $(0-10 \mathrm{ppm})$ were prepared and used as reference standard. The absorbance of sample and standard solutions were read after colour development in a Jenway V6300 spectrophotometer at a wavelength of $380 \mathrm{~nm}$.

\section{Trypsin Inhibitors Determination}

This was determined by the method of Mbata et al. (2009) with slight modification. Approximately, $1.0 \mathrm{~g}$ portion of the sample was extracted by soaking overnight at $4^{\circ} \mathrm{C}$ in $50 \mathrm{~mL}$ of $0.01 \mathrm{M} \mathrm{NaOH}$; $\mathrm{pH}$ was adjusted to 8.4-10.0. The suspension was diluted so that $2 \mathrm{~mL}$ of the sample extract inhibited 40-60\% of standard trypsin used in the analysis. Synthetic benzoyl-dl-arginine-pnitroamide was used as substrate for the inhibition of trypsin. A residual enzyme activity was determined in 2
$\mathrm{mL}$ aliquot of the sample extracts by measuring at 410 $\mathrm{nm}$. Trypsin inhibitor activity (TIA) in term of milligrams pure trypsin inhibited per sample (g) was calculated as:

$$
\mathrm{TIA}=\frac{\left(2.632 \times \mathrm{D} \times \mathrm{A}_{1}\right)}{\mathrm{S}(\mathrm{mg}) \text { pure trypsin inhibited g }{ }^{-1} \text { sample }}
$$

Where $A_{1}=$ change in absorbance due to trypsin inhibition $/ \mathrm{mL}$ diluted sample extract, $\mathrm{D}=$ dilution factor and $\mathrm{S}=$ weight of sample $(\mathrm{g})$

\section{Oligosaccharides Content Determination}

Five $\mathrm{g}$ of sample were added to $50 \mathrm{~mL}$ of $70 \%$ ethanol (v/v) and stirred for $12 \mathrm{~h}$. The content of the flask was filtered through Whatman No. 1 filter paper and the residue was further washed with $25 \mathrm{~mL}$ of $70 \%$ ethanol. The combined filtrate was evaporated in a rotary vacuum evaporator at $40^{\circ} \mathrm{C}$, freeze dried and re-suspended in 10 $\mathrm{mL}$ of distilled water. Ten microliters of the above syrup were spotted in triplicate on chromatographic plates $(19 \times$ $19 \mathrm{~cm})$ coated with cellulose Powder-G. The plates were kept in a chromatographic chamber containing $n$ propanol: ethyl acetate: water $(6: 1: 3)$ as the solvent system (Tanaka et al., 1975). The developed plates were sprayed with $1 \% \alpha$-naphthol in ethyl alcohol containing $10 \%$ orthophosphoric acid to locate the sugar spots. For quantitative estimation, the area $(2 \times 3 \mathrm{~cm})$ corresponding to each oligosaccharide was scraped and soaked in $2 \mathrm{~mL}$ of distilled water kept overnight and filtered through Whatman No. 1 filter paper. The eluted individual oligosaccharides (raffinose and stachyose) were estimated by the method of Tanaka et al. (1975).

\section{In vitro Protein Digestibility Determination}

In vitro protein digestibility of 60 min-boiled samples and $48 \mathrm{~h}$-soaked samples were measured according to the method descried by Saunders et al. (1973), using pepsin and pancreatin digestion method. The digested protein was analyzed for nitrogen using micro Kjeldahl procedure (AOAC, 2005) and expressed as a percent of the total N.

\section{Statistical Analysis}

All experiments were carried out in triplicate, and data were assessed using ANOVA described by Snedecor and Cochran (1987). Differences between the treatment means were separated using Duncan's multiple range tests. Significance was accepted at $\mathrm{P}<0.05$.

\section{Results and Discussion}

Effect of Soaking on Antinutrients Contents of BGC, $B G B$ and $B G W$

The effect of soaking for 12,24 and $48 \mathrm{~h}$ on the antinutrients contents of the samples is shown in Table 1. Raw BGB (7.49 mg/100g) had the lowest amount of saponin while BGW (9.10 mg/100g) had the highest value. A decrease $(\mathrm{P}<0.05)$ in saponin level with increase in soaking time in all the samples was observed. The saponin content reduced significantly $(\mathrm{P}<0.05)$ after soaking for $48 \mathrm{~h}$ by 64,49 and $11 \%$ for BGC, BGW and 
BGB, respectively. After soaking for $48 \mathrm{~h}$, sample BGB was reduced to $6.65 \mathrm{mg} / 100 \mathrm{~g}$ while $\mathrm{BGW}$ had 4.62 $\mathrm{mg} / 100 \mathrm{~g}$. The saponin levels reported in this study were higher than $1.37 \mathrm{mg} / 100 \mathrm{~g}$ reported by Mbagwu et al. (2011) for bambara groundnut after soaking for $48 \mathrm{~h}$. The difference could be attributed to differences in seed coat permeability of the samples which affects the rate of leaching. Saponins are characterized by a bitter taste and foaming properties. The adverse effect of saponins can be overcome by repeated washing with water which makes the food more palatable by reducing the bitterness associated with it (Joshi et al., 2009).

Table 1 Effect of soaking on the antinutrients contents of Bambara groundnut seeds

\begin{tabular}{|c|c|c|c|c|c|c|c|c|c|c|c|}
\hline \multirow[b]{2}{*}{ Sample } & \multirow[b]{2}{*}{ Time } & \multicolumn{2}{|c|}{ Saponin } & \multicolumn{2}{|c|}{ Tannin } & \multicolumn{2}{|c|}{ Phytate } & \multicolumn{2}{|c|}{ Oxalate } & \multicolumn{2}{|c|}{ Trypsin inhibitor } \\
\hline & & $\begin{array}{c}\text { Total } \\
(\mathrm{mg} / 100 \mathrm{~g})\end{array}$ & $\begin{array}{l}\mathrm{RD} \\
(\%)\end{array}$ & $\begin{array}{c}\text { Total } \\
(\mathrm{mg} / 100 \mathrm{~g})\end{array}$ & $\begin{array}{l}\mathrm{RD} \\
(\%)\end{array}$ & $\begin{array}{c}\text { Total } \\
(\mathrm{mg} / 100 \mathrm{~g})\end{array}$ & $\begin{array}{l}\mathrm{RD} \\
(\%)\end{array}$ & $\begin{array}{c}\text { Total } \\
(\mathrm{mg} / 100 \mathrm{~g})\end{array}$ & $\begin{array}{l}\mathrm{RD} \\
(\%)\end{array}$ & $\begin{array}{c}\text { Total } \\
(\mathrm{Tiu} / 100 \mathrm{~g})\end{array}$ & $\begin{array}{l}\mathrm{RD} \\
(\%)\end{array}$ \\
\hline \multirow{4}{*}{ BGC } & 0 & $8.40 \pm 0.01^{\mathrm{a}}$ & 0 & $1.65 \pm 0.01^{\mathrm{a}}$ & 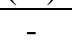 & $850 \pm 0.32^{\mathrm{a}}$ & - & $0.39 \pm 0.07^{\mathrm{a}}$ & - & $17.56 \pm 0.40^{\mathrm{a}}$ & - \\
\hline & $12 \mathrm{~h}$ & $7.01 \pm 0.14^{\mathrm{b}}$ & 17 & $0.01 \pm 0.00^{\mathrm{b}}$ & 99 & $590 \pm 0.09^{\mathrm{b}}$ & 31 & $0.19 \pm 0.03^{\mathrm{b}}$ & 51 & $11.67 \pm 0.21^{\mathrm{b}}$ & 34 \\
\hline & $24 \mathrm{~h}$ & $6.40 \pm 0.05^{\mathrm{c}}$ & 23 & $0.01 \pm 0.00^{\mathrm{b}}$ & 99 & $380 \pm 0.03^{c}$ & 55 & $0.11 \pm 0.01^{\mathrm{b}}$ & 72 & $10.46 \pm 0.11^{\mathrm{c}}$ & 40 \\
\hline & $48 \mathrm{~h}$ & $3.04 \pm 0.22^{\mathrm{d}}$ & 64 & $0.01 \pm 0.00^{\mathrm{b}}$ & 99 & $270 \pm 0.01^{\mathrm{d}}$ & 68 & $0.01 \pm 0.03^{\mathrm{c}}$ & 97 & $10.01 \pm 0.12^{\mathrm{c}}$ & 43 \\
\hline \multirow{4}{*}{ BGW } & 0 & $9.10 \pm 0.04^{\mathrm{a}}$ & - & $0.75 \pm 0.04^{\mathrm{a}}$ & - & $813 \pm 1.42^{\mathrm{a}}$ & - & $0.26 \pm 0.01^{\mathrm{a}}$ & - & $13.15 \pm 0.03^{\mathrm{a}}$ & - \\
\hline & $12 \mathrm{~h}$ & $7.37 \pm 0.09^{b}$ & 19 & $0.01 \pm 0.00^{\mathrm{b}}$ & 99 & $430 \pm 0.04^{\mathrm{b}}$ & 47 & $0.14 \pm 0.04^{\mathrm{b}}$ & 46 & $9.05 \pm 0.35^{\mathrm{b}}$ & 31 \\
\hline & $24 \mathrm{~h}$ & $6.81 \pm 0.11^{\mathrm{c}}$ & 25 & $0.00 \pm 0.00^{\mathrm{b}}$ & 99 & $320 \pm 0.12^{\mathrm{c}}$ & 61 & $0.12 \pm 0.06^{\mathrm{c}}$ & 54 & $8.99 \pm 0.14^{b}$ & 32 \\
\hline & $48 \mathrm{~h}$ & $4.62 \pm 0.05^{\mathrm{d}}$ & 49 & $0.00 \pm 0.00^{\mathrm{b}}$ & 99 & $297 \pm 0.04^{\mathrm{d}}$ & 63 & $0.09 \pm 0.07^{\mathrm{d}}$ & 65 & $8.76 \pm 0.03^{b}$ & 33 \\
\hline \multirow{4}{*}{ BGB } & 0 & $7.49 \pm 0.32^{\mathrm{a}}$ & - & $1.00 \pm 0.06^{\mathrm{a}}$ & - & $970 \pm 0.74^{\mathrm{a}}$ & - & $0.30 \pm 0.07^{\mathrm{a}}$ & - & $16.15 \pm 0.57^{\mathrm{a}}$ & - \\
\hline & $12 \mathrm{~h}$ & $7.32 \pm 0.06^{\mathrm{b}}$ & 2 & $0.01 \pm 0.00^{\mathrm{b}}$ & 99 & $744 \pm 0.36^{\mathrm{b}}$ & 23 & $0.21 \pm 0.01^{\mathrm{b}}$ & 30 & $13.15 \pm 0.56^{\mathrm{b}}$ & 19 \\
\hline & $24 \mathrm{~h}$ & $7.04 \pm 0.18^{\mathrm{c}}$ & 6 & $0.01 \pm 0.00^{\mathrm{b}}$ & 99 & $562 \pm 0.02^{\mathrm{c}}$ & 42 & $0.17 \pm 0.04^{\mathrm{c}}$ & 43 & $10.26 \pm 0.34^{\mathrm{c}}$ & 36 \\
\hline & $48 \mathrm{~h}$ & $6.65 \pm 0.07^{\mathrm{d}}$ & 11 & $0.01 \pm 0.00^{\mathrm{b}}$ & 99 & $437 \pm 0.13^{\mathrm{d}}$ & 55 & $0.10 \pm 0.08^{\mathrm{d}}$ & 67 & $9.89 \pm 0.56^{\mathrm{c}}$ & 39 \\
\hline
\end{tabular}

RD: Reduction, Values are means \pm standard deviation of three determinations. Means in a column not sharing a common superscript letter are significantly $(\mathrm{P}<0.05)$ different as assessed by LSD test. Bambara groundnut white $(\mathrm{BGW})$; Bambara groundnut brown $(\mathrm{BGB})$; Bambara groundnut commercial (BGC)

Highest tannin content was found in raw BGC (1.65 $\mathrm{mg} / 100 \mathrm{~g})$ while $\mathrm{BGW}(0.75 \mathrm{mg} / 100 \mathrm{~g})$ had the lowest value. After soaking for $12 \mathrm{~h}, 99 \%$ reduction in tannin contents of all samples was observed $(\mathrm{P}<0.05)$. The significant reduction in tannin level in soaked samples may be due to removal of seed coat and leaching of tannin (a water soluble phenolic compounds) from the cells into water. The values obtained were lower than the results reported by Udensi et al. (2008) and Onwurafor et al. (2013) where the tannin content of bambara groundnut seeds was investigated. Mazahib et al. (2013) observed that soaking reduced the tannin content of some cowpea varieties, African yam beans, bambara groundnut, and hyacinth and rajina beans to non-detectable levels. Tannins are water soluble phenolic compounds with a high molecular weight and with the ability to form complexes which are not readily digestible. Tannins could reduce availability of proteins because it could complex it and render it unavailable. Tannin is generally present in the seed coat and its removal should eliminate this toxic constituent and improve the nutritive value of food products.

The phytate content of the raw samples ranged between $850 \mathrm{mg} / 100 \mathrm{~g}$ in BGC to $970 \mathrm{mg} / 100 \mathrm{~g}$ in BGB. Soaking significantly $(\mathrm{P}<0.05)$ reduced the phytate content compared to raw samples with greater effect observed as soaking time was elongated. After $48 \mathrm{~h}$ of soaking, the phytate content in BGW and BGB was reduced by 63 and $55 \%$ compared with that of BGC $(68 \%)$. The reduction in phytate level after soaking for various times agreed with the result reported by Udensi et al. (2008) where the phytate level of Mucuna flagellipes reduced from 0.387 to 0.097 (74.9\% reduction) after soaking for $24 \mathrm{~h}$. Bambara groundnut seeds are rich in protein (18.50-20.73\%), therefore, they had high phytate levels (Mazahib et al., 2013). In legumes, phytate are associated with protein bodies (Suleiman et al., 2007) and therefore phytate levels should increase with increasing protein content. Phytic acids form insoluble salts with essential minerals like calcium, iron, magnesium and zinc in food rendering them unavailable for absorption into the blood stream.

Highest amount of oxalate was observed in BGC (0.39 $\mathrm{mg} / 100 \mathrm{~g}$ ) while BGW and BGB had 0.26 and 0.30 $\mathrm{mg} / 100 \mathrm{~g}$, respectively. Soaking significantly $(\mathrm{P}<0.05)$ reduced the oxalate content of all the samples and this decreased as soaking time increased. After $48 \mathrm{~h}$ of soaking, a significant reduction $(97 \%)$ of oxalate level was observed in BGC compared with BGW (65\%) and BGB (67\%). Obasi and Nwogu (2008) reported that soaking caused a significant reduction in the level of oxalate in cowpea. Oxalate combines with calcium to form calcium oxalate which passes through the intestine without being absorbed. Calcium oxalate is responsible for most of the kidney stone formation. Formation of these stones frequently reflects chronic alkalinity of bladder and renal pelvic urine caused by inflectional bacterial that hydrolyses urea, releasing ammonia (Olaleye et al., 2013).

The trypsin inhibitors contents of the samples ranged between 13.15 to $17.56 \mathrm{Tiu} / 100 \mathrm{~g}$ with $\mathrm{BGW}$ having the lowest value. The levels of trypsin inhibitors after soaking reduced $(\mathrm{P}<0.05)$ with increase in soaking time. Soaking for $48 \mathrm{~h}$ significantly $(\mathrm{P}<0.05)$ reduced the level of trypsin inhibitors in $\mathrm{BGW}$ to $8.76 \mathrm{Tiu} / 100 \mathrm{~g}$ while highest level was recorded in BGC (10.01 Tiu/100g). The trypsin inhibitor levels after soaking for $48 \mathrm{~h}$ were still higher 
than the values of $4.28 \mathrm{Tiu} / 100 \mathrm{~g}$ reported by Fadahunsi and Sanni (2010) for soaked bambara groundnut seeds.

Effect of Boiling on Antinutrients Contents of BGC, $B G B$ and $B G W$

The effect of boiling for different periods on the antinutrients contents of BGC, BGB and BGW is shown in Table 2. It was observed that the saponins content of raw $\mathrm{BGC}$ was found to be $8.40 \mathrm{mg} / 100 \mathrm{~g}$ while that of BGW and BGB were 9.10 and $7.49 \mathrm{mg} / 100 \mathrm{~g}$, respectively. Boiling for $30 \mathrm{~min}$ significantly $(\mathrm{P}<0.05)$ reduced the levels of saponin in BGC (by $28 \%$ ), BGW (by $11 \%$ ) and BGB (by 5\%). Increasing the boiling time to 60 min significantly $(\mathrm{P}<0.05)$ reduced the levels of saponin of BGC to 5.32 while that of $\mathrm{BGW}$ and $\mathrm{BGB}$ were reduced to 6.01 and $6.78 \mathrm{mg} / 100 \mathrm{~g}$, respectively. The values were higher than that of bambara groundnut $(0.43$ $\mathrm{mg} / 100 \mathrm{~g})$, cowpea $(0.25 \mathrm{mg} / 100 \mathrm{~g})$ and soybean $(0.39$ $\mathrm{mg} / 100 \mathrm{~g}$ ) reported by Mbagwu et al. (2011). However, the values were lower than that of whole and defatted bambara groundnut seeds, 13.8 and $10.1 \mathrm{mg} / 100 \mathrm{~g}$ of saponin, respectively, reported by Olaleye et al. (2013).

Raw BGC (1.65 mg/100g) had the highest tannin contents while BGW $(0.75 \mathrm{mg} / 100 \mathrm{~g})$ had the lowest value. Significant $(\mathrm{P}<0.05)$ reduction in tannin contents of BGW and BGB by 49 and $31 \%$ was observed after boiling for 60 min while BGC was reduced by $60 \%$. The reduction in tannin level with cooking time is in agreement with the report of Adewusi and Osuntokun (1989) that tannin is possible culprit in the hard-to-cook phenomenon of some beans and that it could play a contributory role. Mazahib et al. (2013) reported that tannin content of bambara groundnut was found to be $4.60 \mathrm{mg} / 100 \mathrm{~g}$ while Abiodun and Adepeju (2011) reported $2.40 \mathrm{mg} / 100 \mathrm{~g}$ for bambara seed flour. The results of these findings were in disagreement with earlier observation by Adewusi and Osuntogun (1989) that boiling did not appreciably affect the tannin content of bambara groundnut and lima beans.

The level of phytate in raw samples BGC (850 $\mathrm{mg} / 100 \mathrm{~g})$ was higher than that of BGW $(813 \mathrm{mg} / 100 \mathrm{~g})$ and BGB $(610 \mathrm{mg} / 100 \mathrm{~g})$. The phytate content of the samples was significantly $(\mathrm{P}<0.05)$ reduced with increase in boiling time. After boiling for $60 \mathrm{~min}$, greater reduction was observed in BGB (46\%) while BGC and BGW were reduced by 19 and $23 \%$, respectively. This result agrees with that reported by Mazahib et al. (2013) that boiling reduced the level of phytate but the reduction obtained in this study was greater than that obtained when raw bambara groundnut seeds was boiled for the same period (Mazahib et al. 2013). The values were also lower than that of boiled and whole bambara groundnut seeds were 14.4 and $17.5 \mathrm{mg} / 100 \mathrm{~g}$, respectively as reported by Olaleye et al. (2013). According to El Maki et al. (2007), the difference in the loss of phytic acid during boiling could probably be explained on the basis that phytate activity at a temperature of $40-55^{\circ} \mathrm{C}$ may degrade inositol hexaphosphate to the pentaphosphate or lower molecular weight forms. It was also reported that phytic acid content decreased during boiling because insoluble complexes between phytate and other compounds were formed and accordingly the amount of free phytate will be reduced (Mazahib et al., 2013).

Raw BGC had the highest oxalate content $(0.39$ $\mathrm{mg} / 100 \mathrm{~g})$, while BGW had the lowest $(0.26 \mathrm{mg} / 100 \mathrm{~g})$. The oxalate content of the raw bambara groundnut seeds decreased $(\mathrm{P}<0.05)$ with increase in boiling time. After 30 min of boiling, the levels of oxalate in BGC, BGW and BGB were decreased to 0.13 and $0.21 \mathrm{mg} / 100 \mathrm{~g}$, respectively, compared with that of BGC $(0.17 \mathrm{mg} / 100 \mathrm{~g})$. Increase in boiling time to $60 \mathrm{~min}$ did not have any significant effect on the level of oxalate in the BGW $(58 \%)$ and $\mathrm{BGB}(34 \%)$ but significantly $(\mathrm{P}<0.05)$ reduced that of BGC by $67 \%$. The decreases in oxalate content of the samples after boiling were in conformity with the results reported by Ijarotimi et al. (2009) and Olaleye et al. (2013) that boiling reduced the oxalate content of bambara groundnut seeds.

The trypsin inhibitor (TI) of BGC, BGW and BGB are 17.56, 13.15 and $16.15 \mathrm{Tiu} / 100 \mathrm{~g}$, respectively. The activity of $\mathrm{TI}$ in the samples boiled for different times showed significant decrease $(\mathrm{P}<0.05)$ when compared with that of raw samples with greater effect observed as boiling time increased. After $60 \mathrm{~min}$ of boiling, BGC $(67 \%)$ exhibited higher reduction in TI levels than that of BGW (40\%) and BGB (43\%). Boiling significantly affected TI activity and the inhibition effect depends on time of cooking. This is in line with the report of Adeyeye (2001) who stated that reduction in trypsin inhibitors activity occurred mainly during the first step of cooking for both early and hard-to-cook beans. However, apparent retention of trypsin inhibitory activity was reduced to about $50 \%$ by applying heat treatments till beans were softened. Thus, the residual trypsin inhibitors will be resistant, since heat treatment must have deactivated the heat labile trypsin inhibitors. The non-protein trypsin inhibitory activity was reported to compose 27 to $55 \%$ of the total trypsin inhibitory activity in soybean and 4 to $15 \%$ of the total activity of winged bean (Apata and Ologhobo, 1997). Adewusi et al. (2008) reported that boiling reduced the level of trypsin inhibitors after 60 and $90 \mathrm{~min}$ by 49.1 and $50.1 \%$ in Mucuna flagellipes. It can be concluded from the results that boiling can reduce to a significant level the trypsin inhibitors in the newly developed bambara groundnut seeds cultivars.

Effect of Processing Treatments on Oligosaccharides Content of $B G C, B G W$ and $B G B$

The levels of raffinose and stachyose in the raw and processed BGC, BGW and BGB are presented in Table 3. Raw BGW had lower level of raffinose $(1.30 \mathrm{~g} / 100 \mathrm{~g})$ and stachyose $(0.86 \mathrm{~g} / 100 \mathrm{~g})$ than that of BGB (1.79 and 1.22 $\mathrm{g} / 100 \mathrm{~g}$, respectively) and BGC (2.05 and $1.48 \mathrm{~g} / 100 \mathrm{~g}$, respectively). The concentrations of raffinose in the samples were higher than that of red bean $(0.89 \mathrm{~g} / 100 \mathrm{~g})$ and chick pea $(1.00 \mathrm{~g} / 100 \mathrm{~g})$ reported by Ruiz-Teran and Owens (1996). The levels of stachyose in the samples were lower than that of soybeans $(2.08 \mathrm{~g} / 100 \mathrm{~g})$ reported by Mercedes et al. (1999). 
Table 2 Effect of boiling on the antinutrients content of Bambara groundnut seeds

\begin{tabular}{|c|c|c|c|c|c|c|c|c|c|c|c|}
\hline \multirow[b]{2}{*}{ Sample } & \multirow[b]{2}{*}{ Time } & \multicolumn{2}{|c|}{ Saponin } & \multicolumn{2}{|c|}{ Tannin } & \multicolumn{2}{|c|}{ Phytate } & \multicolumn{2}{|c|}{ Oxalate } & \multicolumn{2}{|c|}{ Trypsin inhibitor } \\
\hline & & $\begin{array}{c}\text { Total } \\
(\mathrm{mg} / 100 \mathrm{~g})\end{array}$ & $\begin{array}{l}\mathrm{RD} \\
(\%)\end{array}$ & $\begin{array}{c}\text { Total } \\
(\mathrm{mg} / 100 \mathrm{~g})\end{array}$ & $\begin{array}{l}\mathrm{RD} \\
(\%)\end{array}$ & $\begin{array}{c}\text { Total } \\
(\mathrm{mg} / 100 \mathrm{~g})\end{array}$ & $\begin{array}{l}\mathrm{RD} \\
(\%)\end{array}$ & $\begin{array}{c}\text { Total } \\
(\mathrm{mg} / 100 \mathrm{~g})\end{array}$ & $\begin{array}{l}\mathrm{RD} \\
(\%)\end{array}$ & $\begin{array}{c}\text { Total } \\
(\text { Tiu/100g) }\end{array}$ & $\begin{array}{l}\mathrm{RD} \\
(\%)\end{array}$ \\
\hline \multirow{3}{*}{ BGC } & 0 & $8.40 \pm 0.04^{\mathrm{a}}$ & - & $1.65 \pm 0.01^{\mathrm{a}}$ & - & $850 \pm 0.32^{\mathrm{a}}$ & - & $0.39 \pm 0.01^{\mathrm{a}}$ & , & $17.56 \pm 1.25^{\mathrm{a}}$ & - \\
\hline & $30 \mathrm{~min}$ & $6.04 \pm 0.27^{\mathrm{b}}$ & 28 & $0.96 \pm 0.01^{\mathrm{b}}$ & 42 & $799 \pm 13.02^{b}$ & 6 & $0.17 \pm 0.04^{\mathrm{b}}$ & 56 & $7.26 \pm 0.10^{\mathrm{b}}$ & 59 \\
\hline & $60 \mathrm{~min}$ & $5.32 \pm 0.15^{\mathrm{c}}$ & 37 & $0.66 \pm 0.01^{\mathrm{c}}$ & 60 & $685 \pm 17.00^{\mathrm{c}}$ & 19 & $0.13 \pm 0.03^{\mathrm{c}}$ & 67 & $5.74 \pm 0.14^{\mathrm{c}}$ & 67 \\
\hline \multirow{3}{*}{ BGW } & 0 & $9.10 \pm 0.04^{\mathrm{a}}$ & - & $0.75 \pm 0.04^{\mathrm{a}}$ & - & $813 \pm 1.42^{\mathrm{a}}$ & - & $0.26 \pm 0.01^{\mathrm{a}}$ & - & $13.15 \pm 0.03^{\mathrm{a}}$ & - \\
\hline & $30 \mathrm{~min}$ & $8.11 \pm 0.03^{b}$ & 11 & $0.41 \pm 0.01^{\mathrm{b}}$ & 45 & $645 \pm 3.79^{\mathrm{b}}$ & 21 & $0.13 \pm 0.04^{\mathrm{b}}$ & 50 & $8.34 \pm 0.45^{\mathrm{b}}$ & 37 \\
\hline & $60 \mathrm{~min}$ & $6.01 \pm 0.07^{\mathrm{c}}$ & 34 & $0.38 \pm 0.00^{\mathrm{c}}$ & 49 & $630 \pm 3.11^{c}$ & 23 & $0.11 \pm 0.06^{\mathrm{c}}$ & 58 & $7.88 \pm 0.34^{\mathrm{b}}$ & 40 \\
\hline \multirow{3}{*}{ BGB } & 0 & $7.49 \pm 0.01^{\mathrm{a}}$ & - & $1.00 \pm 0.06^{\mathrm{a}}$ & - & $670 \pm 7.70^{\mathrm{a}}$ & 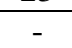 & $0.29 \pm 0.10^{\mathrm{a}}$ & - & $16.15 \pm 0.07^{\mathrm{a}}$ & - \\
\hline & $30 \mathrm{~min}$ & $7.14 \pm 0.02^{\mathrm{b}}$ & 5 & $0.82 \pm 0.03^{\mathrm{b}}$ & 18 & $610 \pm 3.40^{\mathrm{b}}$ & 9 & $0.21 \pm 0.01^{\mathrm{b}}$ & 28 & $10.23 \pm 0.06^{\mathrm{b}}$ & 37 \\
\hline & $60 \mathrm{~min}$ & $6.78 \pm 0.01^{\mathrm{c}}$ & 9 & $0.69 \pm 0.02^{\mathrm{c}}$ & 31 & $365 \pm 4.50^{\mathrm{c}}$ & 46 & $0.19 \pm 0.04^{\mathrm{b}}$ & 34 & $9.15 \pm 0.01^{\mathrm{c}}$ & 43 \\
\hline
\end{tabular}

RD: Reduction, Values are means \pm standard deviation of three determinations. Means in a column not sharing a common superscript letter are significantly $(\mathrm{P}<0.05)$ different as assessed by LSD test. Bambara groundnut white $(\mathrm{BGW})$; Bambara groundnut brown $(\mathrm{BGB})$; Bambara groundnut commercial (BGC)

Table 3 Effect of soaking and boiling on oligosaccharides content of Bambara groundnut samples

\begin{tabular}{|c|c|c|c|c|c|c|}
\hline \multirow{2}{*}{ Sample } & \multicolumn{2}{|c|}{ Treatments } & \multicolumn{2}{|l|}{ Raffinose } & \multicolumn{2}{|c|}{ Stachyose } \\
\hline & Methods & Time & Concentration $(\mathrm{g} / 100 \mathrm{~g})$ & Loss (\%) & Concentration $(\mathrm{g} / 100 \mathrm{~g})$ & Loss $(\%)$ \\
\hline \multirow{6}{*}{ BGC } & Raw seeds & & $2.05 \pm 0.02^{\mathrm{a}}$ & - & $1.48 \pm 0.04^{\mathrm{a}}$ & - \\
\hline & & $12 \mathrm{~h}$ & $1.52 \pm 0.01^{\mathrm{b}}$ & 26 & $1.10 \pm 0.05^{\mathrm{b}}$ & 26 \\
\hline & Soaking & $24 \mathrm{~h}$ & $1.28 \pm 0.07^{\mathrm{d}}$ & 38 & $0.92 \pm 0.12^{\mathrm{c}}$ & 38 \\
\hline & & $48 \mathrm{~h}$ & $1.10 \pm 0.02^{\mathrm{e}}$ & 46 & $0.65 \pm 0.08^{\mathrm{e}}$ & 56 \\
\hline & Boiling & $30 \mathrm{~min}$ & $1.34 \pm 0.04^{\mathrm{c}}$ & 35 & $0.86 \pm 0.02^{\mathrm{d}}$ & 42 \\
\hline & & $60 \mathrm{~min}$ & $1.17 \pm 0.03^{\mathrm{f}}$ & 43 & $0.61 \pm 0.16^{\mathrm{e}}$ & 59 \\
\hline \multirow{6}{*}{ BGW } & Raw seeds & & $1.30 \pm 0.07^{\mathrm{a}}$ & - & $0.86 \pm 0.11^{\mathrm{a}}$ & - \\
\hline & & $12 \mathrm{~h}$ & $0.98 \pm 0.01^{\mathrm{b}}$ & 25 & $0.70 \pm 0.16^{\mathrm{b}}$ & 13 \\
\hline & Soaking & $24 \mathrm{~h}$ & $0.81 \pm 0.03^{\mathrm{c}}$ & 38 & $0.62 \pm 0.05^{\mathrm{c}}$ & 23 \\
\hline & & $48 \mathrm{~h}$ & $0.69 \pm 0.03^{\mathrm{d}}$ & 47 & $0.52 \pm 0.08^{\mathrm{d}}$ & 35 \\
\hline & Boiling & $30 \mathrm{~min}$ & $0.81 \pm 0.12^{\mathrm{c}}$ & 38 & $0.70 \pm 0.15^{\mathrm{b}}$ & 13 \\
\hline & & $60 \mathrm{~min}$ & $0.65 \pm 0.05^{\mathrm{e}}$ & 50 & $0.60 \pm 0.07^{\mathrm{c}}$ & 25 \\
\hline \multirow{6}{*}{ BGB } & Raw seeds & & $1.79 \pm 0.03^{\mathrm{a}}$ & - & $1.22 \pm 0.15^{\mathrm{b}}$ & - \\
\hline & & $12 \mathrm{~h}$ & $1.30 \pm 0.06^{\mathrm{b}}$ & 27 & $0.70 \pm 0.04^{b}$ & 43 \\
\hline & Soaking & $24 \mathrm{~h}$ & $0.89 \pm 0.01^{\mathrm{d}}$ & 50 & $0.70 \pm 0.01^{\mathrm{b}}$ & 43 \\
\hline & & $48 \mathrm{~h}$ & $0.63 \pm 0.04^{\mathrm{f}}$ & 65 & $0.52 \pm 0.21^{\mathrm{c}}$ & 57 \\
\hline & Boiling & $30 \mathrm{~min}$ & $0.94 \pm 0.03^{c}$ & 47 & $0.70 \pm 0.08^{b}$ & 43 \\
\hline & & $60 \mathrm{~min}$ & $0.74 \pm 0.01^{\mathrm{e}}$ & 59 & $0.52 \pm 0.03^{c}$ & 57 \\
\hline
\end{tabular}

Values are means \pm standard deviation of three determinations. Means in a column not sharing a common superscript letter are significantly $(\mathrm{P}<0.05)$ different as assessed by LSD test. Bambara groundnut white (BGW); Bambara groundnut brown (BGB); Bambara groundnut commercial (BGC)

Soaking significantly $(\mathrm{P}<0.05)$ reduced the levels of the raffinose and stachyose in the samples with greater reduction observed as soaking time increased. After $48 \mathrm{~h}$ of soaking, the loss in raffinose and stachyose of BGC, BGB and BGW were 46, 65 and $47 \%$ and 56, 57 and $35 \%$, respectively. Nnanna and Phillips (1988) had reported that the levels of raffinose and stachyose sugars in cowpea (Vigna unguilata) decreased with increase in time of soaking from 12 to $24 \mathrm{~h}$. Similar observation was reported by Mulimani et al. (1997) that soaking of whole soybean seeds for $16 \mathrm{~h}$ led to a decrease of $80.3 \%$ of raffinose and $44.8 \%$ of stachyose. The varying degree of removal of raffinose and stachyose from legumes during soaking could be attributed to the differential solubility of individual sugars, their diffusion rates and leaching (Price et al., 1988; Upadhyay and Garcia, 1988).

Boiling led to significant $(\mathrm{P}<0.05)$ decrease in the levels of raffinose and stachyose in the samples compared to raw samples. Boiling for $60 \mathrm{~min}$ resulted in a significant $(\mathrm{P}<0.05)$ reduction of raffinose in BGC $(1.17$ $\mathrm{g} / 100 \mathrm{~g})$, BGW (0.74 g/100g) and BGB (0.65 g/100g). The stachyose level of BGC was also reduced to 0.61 while BGW had the lowest value of $0.52 \mathrm{~g} / 100 \mathrm{~g}$. Somiari and Balogh (1993) reported that cooking of cowpea for 50 min reduced the raffinose content to $44 \%$ and stachyose to 28.6\%. Mulimani and Devendra (1998) reported a decrease in the levels of the raffinose family of sugars after cooking of soybean for $60 \mathrm{~min}$. The decrease in the level of raffinose, stachyose and verbascose during cooking might be attributed to hydrolysis of these oligosaccharides into disaccharides and monosaccharides or to the formation of other compounds which are subsequently leached out (Mulimani and Devendra, 1998).

Table 4 Effect of soaking and boiling on in-vitro protein digestibility of Bambara groundnut samples 


\begin{tabular}{|c|c|c|}
\hline Treatments & Sample & In-vitro digestibility (\%) \\
\hline \multirow{3}{*}{ Raw seeds } & BGC & $56.77 \pm 0.04^{\mathrm{i}}$ \\
\hline & BGW & $64.42 \pm 0.13^{\mathrm{h}}$ \\
\hline & BGB & $68.35 \pm 0.09^{f}$ \\
\hline \multirow{3}{*}{ Soaking } & BGC & $66.42 \pm 0.02^{\mathrm{g}}$ \\
\hline & BGW & $73.56 \pm 0.07^{\mathrm{e}}$ \\
\hline & BGB & $79.10 \pm 0.13^{\mathrm{d}}$ \\
\hline \multirow{3}{*}{ Boiling } & BGC & $82.89 \pm 0.01^{\mathrm{c}}$ \\
\hline & BGW & $87.48 \pm 0.05^{\mathrm{b}}$ \\
\hline & BGB & $89.34 \pm 0.04^{\mathrm{a}}$ \\
\hline
\end{tabular}

Values are means \pm standard deviation of three determinations. Means in a column not sharing a common superscript letter are significantly $(\mathrm{P}<0.05)$ different as assessed by LSD test. Bambara groundnut white (BGW); Bambara groundnut brown (BGB); Bambara groundnut commercial (BGC)

Effect of Processing Treatments on IVPD of BGC, $B G B$ and $B G W$

The effects of soaking for $48 \mathrm{~h}$ and boiling for $60 \mathrm{~min}$ on IVPD of BGC, BGW and BGB are shown in Table 4. Lower IVPD level was observed in raw BGC $(56.77 \%)$ compared with that of raw BGW $(64.42 \%)$ and BGB $(68.35 \%)$. Soaking of the samples for $48 \mathrm{~h}$ significantly $(\mathrm{P}<0.05)$ increased the IVPD of BGC, BGW and BGB to 66.42, 73.56 and $79.10 \%$. However, highest IVPD value was observed in BGB $(89.34 \%)$ compared with that of BGW $(87.48 \%)$ and BGC $(82.89 \%)$. The improvement in the protein digestibility of all the samples after soaking may be due to leaching-out of phytic acid, tannin and polyphenols which is known to interact with protein to form complexes. Heat processing has been reported to increase the digestibility of protein by destroying protease inhibition (Abbey and Benezi, 1988). Contrary to our findings, Osman (2007) and Yagoub and Abdalla (2007) found that cooking significantly decreased IVPD in Dicholas lablab seeds and bambara groundnut. Improvement of protein digestibility after boiling could be attributed to the reduction or elimination of different antinutrients. Thus, phytic acid, as well as condensed tannins and polyphenols are known to interact with protein to form complexes. These interactions could increase the degree of cross-linking, decreasing the solubility of proteins making protein complexes which impair protease access to labile peptide bonds (Genovese and Lajolo, 1996). In addition, thermal processing promoted structural changes of protein such as globulin, thereby increasing chain flexibility and accessibility to proteases (Swaisgood and Catignani, 1991).

\section{Conclusion}

Soaking was more effective in reducing the antinutritional factors of the samples with the control seeds exhibiting lower values than the newly developed seeds. Processing methods reduced the oligosaccharides content of the samples. The raffinose content of BGB and BGW were significantly lowered after boiling for $60 \mathrm{~min}$ than that of BGC. However, BGC had lower stachyose content compared with BGB and BGW after soaking for $48 \mathrm{~h}$. Soaking and boiling led to an improvement in protein digestibility of the seeds with BGB having the highest values after boiling for $60 \mathrm{~min}$.

\section{References}

Abbey BW, Berezzi PE. 1988. Influence of processing on the digestibility of African yam bean flour. Nutrition Report International, 32: 819-827.

Abiodun AO, Adepeju AB. 2011. Effect of processing on the chemical, pasting and anti- nutritional composition of bambara nut (Vigna subterranea L. verdc) flour. Advance Journal of Food Science and Technology, 3(4): 224-227.

Adebowale KO, Lawal OS. 2003. Foaming, gelation and electrophoretic physicochemical characterization of bambara groundnut (Voandzeia subterranea) characteristics of mucuna bean (Mucuna pruriens) protein concentrates. Food Chemistry, 83: 237-246.

Adebowale YA, Adeyemi IA, Oshodi AA. 2005. Functional and physicochemical properties of flours of six mucuna species. African. Journal of Biotechnology, 4: 416-468.

Adewusi SRA, Osuntogun BA. 1989. Effect of cooking on tannin, trypsin inhibitor activity and in-vitro digestibility of some legume seeds in Nigeria. Nigerian Food Journal, 9: 139-145.

Adewusi SRA, Udio AJ, Osuntokun BA. 2008. Studies on the carbohydrate content of breadfruit (Artocarpus communis Forst) from South-Western Nigeria. Starch Nutrition, 8: 289-294.

Adeyeye EI. 2001. Effects of processing on the nutritional and antinutritional factors of Arachis hypogeae (Groundnut) seed flour. International Journal of Chemical Science, 4(1): 131-142.

Agbenorhevi JK, Oduro I, Ellis WO, Aodakpi VD, Eleblu SE. 2007. Effect of soaking, autoclaving and repeated boiling on oligosaccharides in cowpea. Nigerian Food Journal, 25(2): 8894.

Akinjayeju O, Bisiriyu KT. 2004. Comparative studies of some properties of undehulled mechanically de-hulled and manually de-hulled cowpea flours. International Journal of Food Science and Technology, 39: 355-360.

Alonso R, Aguirre A, Matzo F. 2000. Effect of traditional processing methods on antinutritional and in vitro digestibility of protein and starch in faba and kidney beans. Food Chemistry, 68: $159-165$.

AOAC, 2005. Official methods of analysis. $15^{\text {th }}$ ed. Association of Official Chemists, Washington, DC.

Apata DF, Ologhobo D. 1997. Trypsin inhibitor and other antinutritional factors in tropical legume seeds. Tropical Sciences, 37: 52-59.

Aremu MO, Olaofe O, Akintayo ET. 2006. Mineral and amino acid composition of bambara groundnut (Vigna subterranean) and Kerstings groundnut (Kerstingiella geocarpa) flour. International Journal of Chemistry, 16: 57-64.

Barbour EK, Kallas M, Farran MT. 2001. Immune response to Newcastle disease virus in broilers: A useful model for the assessment of detoxification of evil seeds. Scientific and Technical Review of the International des Epizooties, 20: 785-790.

Brunner JH. 1984. Direct spectrophotometric determination of saponin. Analytical Chemistry, 34: 1314-1326.

Bryan JA. 2000. Nitrogen-fixing trees and shrubs: A basic resource of agro forestry. In V.A.S. Ashton, F.I. (ed.). The silvicultural basics for agro forestry systems. CRC Press, Baton Rouge, LA. Pp. 41-60.

El-Adawy TA. 2002. Nutritional composition and anti-nutritional factors of chickpeas (Cicer arietinum L) undergoing different cooking methods and germination. Plant Foods for Human Nutrition, 57(1): 83-87.

El-Maki HB, Abdel-Rahman SM, Idris WH, Hassan AB, Babiker EE, El-Tinay AH. 2007. Content of antinutritional factors and $\mathrm{HCl}$ extractability of mineral from white bean (Phaseolus vulgaris). Cultivars: Influence of soaking and/or cooking. Food Chemistry, 100: 362-368. 
Fadahunsi IF, Jonathan SG, Garuba EO. 2011. Fermentation studies during the production of 'Iru' from bambara nut (Voandzeia subterranean L. Thouars), an indigenous condiment from South-Western, Nigeria. Electronic Journal of Environmental, Agriculture and Food Chemistry, 10(1): 1829-1836.

Fadahunsi IF, Sanni AI. 2010. Chemical and biochemical changes in bambara nut (Voandzeia subterranea (L) Thouars) during fermentation of 'tempeh'. Electronic Journal of Environmental, Agriculture and Food Chemistry, 9(2): 275-283.

Falade SO, Owoyomi CE, Adewusi SRA. 2005. Chemical composition and starch hydrolysis of acacia colei and acacia tumida seeds. Cereal Chemistry, 82(5): 479-484.

Farran MT, Dakessian PB, Darwish AH, Uwayjan MG, Dbouk HK, Seliman FT, Ashkarian VM. 2001. Performance of broilers production and egg quality parameters of laying hens fed $60 \%$ raw and treated common vetch (Vicia ervilia) seeds. Poultry Science, 80: 203-208.

Fernandez NM, Aranda P, Lopez-Jurado M, Urbano G, Estrelia I, Sotomayor C, Diaz C, Prodanov M, Frias J, Vidal-Valverde C. 1993. Effect of processing on some ant nutritive factors of faba beans influence on protein digestibility and food intake in rats. In: Recent advances of research in antinutritional factors in Legumes seeds. Wageningen Per, Wageningen,Netherlands. pp 467-471.

Genovese MI, Lajolo FM. 1996. In vitro digestibility of albumin proteins from Phaseolus vulgaris L. effect of chemical modification. Journal of Agriculture and Food Chemistry, 44: 3022-3028

Genta HD, Alvarez NV, Santana MS. 2002. Production and acceptance of a soy candy. Journal of Food Engineering, 53: 199-202.

Ghadge PN, Vairagar PR, Prasad K. 2008. Physical Properties of Chick Pea Split (Ciceranetinum L). Agricultural Engineering International, the CIGR Ejournal Manuscript FP 07039 Vol. X.

Ijarotimi OS, Oyewo MT, Oladeji BS. 2009. Chemical, functional and sensory properties of roasted bambara groundnut (Vigna subterranea L. Verdc) and cooked banana (Musa spp., abb genome) weaning diet. African Journal of Food Science, 3(5): $139-146$.

Joshi DC, Katiyar RC, Khan MY, Banerji R, Misra G, Sligam SK. 2009. Studied on mahna (Bassia latifolia) seed cake saponin. Indian Journal of Nutrition, 16: 13-17.

Khowhar S, Chauhan BM. 1997. Antinutritional factors in Moth Bean (Vigna aconilitilolia): Varietal Differences and Effects of Methods of Domestic Processing and Cooking. Food Chemistry, 59(3): 367-371.

Mazahib AM, Nuha MO, Salawa IS, Babiker EE. 2013. Some nutrition attributes of bambara groundnut as influenced by domestic processing. International Food Research Journal, 20(3): 1165-1171.

Mbagwu FN, Okafor VU, Ekeanyanwu J. 2011. Phytochemical screening on four edible legumes (Vigna subterranea, Glycine max, Arachis hypogeal and Vigna unguiculata) found in eastern Nigeria. African Journal of Plant Science, 5(6): 370-372.

Mbata TI, Ikenebomeh MJ, Alaneme JC. 2009. Studies on the microbiological, nutrient composition and anti-nutritional contents of fermented maize flour fortified with bambara groundnut (Vigna subterranea L). African Journal of Food Science, 3(6): 165-171.

Mercedes M, Carmen B, Gernma A, Mercedes MD, Carmen C. 1999. The Investigation of antinutritional factors in Phaseolus vulgaris. Environmental and varietal differences. Biotechnology, Agronomy, Society and Environment, 3(4): 210-216.

Mulimani VH, Devendra S. 1998. Effect of soaking, cooking and crude $\alpha$-galactosidase treatment on the oligosaccharide content of red gram flour. Food Chemistry, 61(4): 475-479.

Mulimani VH, Tippeswamy S, Ramalingam L. 1997. Effect of soaking, cooking and $\alpha$-galactosidase treatment on the oligosaccharide content of soyabean flour. Food Chemistry, 59:279-282.
Nnanna IA, Phillips RD. 1988. Changes in oligosaccharide content, enzyme activities and dry matter during controlled germinated of cowpeas (Vigna unguiculata). Journal of Food science, 53(6): 1782-1786.

Obasi HE, Nwogu CO. 2008. Effect of soaking time on proximate and mineral compositions and antinutritional factors of yellow maize (Zea mays). Nigerain Food Journal, 26(3): 69-77.

Okonkwo SI, Opara MF. 2010. The analysis of bambara nut (Voandzeia subterranea (L) Thouars) for sustainability in Africa. Research Journal of Applied Science, 5(6): 394-396.

Olaleye AA, Adeyeye EI, Adesina AJ. 2013. Chemical composition of bambara groundnut ( $V$. subterranea L. verdc) seed pacts. Bangladesh Journal of Scientific and Industrial Research, 48(3): 167-178.

Onwurafor EU, Onweluzo JC, Umunnakwe II. 2013. Effect of malting periods on the chemical and antinutrients contents of mung bean (Vigna radiate) ovarudi flour. Being a paper presented at conference of Bioversity International, Accra, Ghana. 25-27 September, 2013.

Osungbade OR, Gbadamosi OS, Adiamo OQ. 2016. Effects of cooking and fermentation on the chemical composition, functional properties and protein digestibility of sandbox (Hura crepitans) seeds. Journal of Food Biochemistry, 40(6): 754-765.

Osman MA. 2007. Effect of different processing methods, on nutrient composition, antinutritional factors, and in vitro protein digestibility of Dolichos lablab bean [Lablab purpuresus (L) Sweet]. Pakistan Journal of Nutrition, 6: 299-303.

Piyarat S. 2008. Structure and functional properties of starch and flour from bambara groundnut. Journal of Science and Technology, 30:51-56.

Price ML, Butler LG. 1977. Rapid visual estimation and spectrophotometric determination of tannin content of sorghum grain. Journal of Agriculture and Food Chemistry, 25: 12681273.

Price KR, Eagles J, Fenwick GR. 1988. Saponin composition of 13 varieties of legumes seed using fast atom bombardment mass spectrometry. Journal of Science and Food Agriculture, 42: 183193.

Ruiz-Teran F, Owens JD. 1996. Chemical and enzymatic changes during the fermentation of bacteria-free soya bean tempeh. Journal of Science and Food Agriculture, 71, 523.

Saunder RM, Connor MA, Booth AN, Bickhoff EN, Kohler CO. 1973. Measurement of digestibility of alfa-alfa protein concentrates by in vitro methods. Journal of Nutrition, 103: $530-535$.

Snedecor GW, Cochran WG. 1987. Statistical Methods (17th ed., pp. 221 - 222). Ames, IA: The Iowa State University Press.

Somiari RT, Balogh E. 1993. Effect of soaking, cooking and $\alpha-$ galactosidase treatment on the oligosaccharide content of cowpea flours. Journal of Food Science and Agriculture, 61: 339-343.

Suleiman MA, Mohammed AA, Elhadi AI, Babiker EE, ElTinay AH. 2007. Changes in chemical composition, phytate activity and minerals extractability of sprouted lentil cultivars. Journal of Biological Sciences, 7: 776-780.

Swaisgood E, Catignani LG. 1991. Protein digestibility in vitro methods of assessment. pp. 185-230. In: Advances in Food and Nutrition Research. Kinsella JE (ed). Academic Press, San Diego, CA, USA.

Tanaka M, Thanankul D, Lee TC, Chichester LO. 1975. A simplified method for the quantitative determination of sucrose, raffinose and stachyose in legume seeds. Journal of Food Science, 40: 1087-1088.

Udensi EA, Onwuka GI, Okoli EG. 2008. Effect of process on the levels of some antinutritional factors in mucuna utilities. Plant Products Research Journal, 8(1): 1-6.

Upadhyay JK, Garcia VV. 1988. Effect of soaking and cooking on reduction of oligosaccharides of cowpea (Vigna unguiculata (L) Walp). Philippine Journal of Food Science and Technology, 12: 21-28. 
Wang N, Hatcher DW, Toews R, Gawalko EJ. 2009. Influence of cooking and dehulling on nutritional composition of several varieties of lentils (lens culinaris). Food Science and Technology, 42: 842-848.

Wheeler EL, Ferrel RE. 1971. A method for phytic acid determination in wheat and wheat fractions. Cereal Chemistry, 48: 312 .
Yagoub AA, Abdalla AA. 2007. Effect of domestic processing methods on chemical composition, in vitro digestibility of protein and starch and functional properties of bambara groundnut (Voandzeia subterranea) seed. Research Journal of Agriculture and Biological Sciences, 3: 24-34. 